\title{
THE WORLD OF DROP-SHIP ETAILING: EFFECTIVE WAY TO USE E-BAY
}

\author{
Jack D. Shorter, Texas A\&M University-Kingsville \\ *Karen A. Forcht, North Carolina A\&T State University \\ Alicia Aldridge, Appalachian State University \\ Susan E. Kruck, James Madison University
}

Key Words: Drop-ship eTailing, eBay, startups, eBIZ, Business Plan, Product Sourcing, Dropshipping, Small Business Administration, Homebased Business

\begin{abstract}
This paper explores the use of the Internet for home-based and small businesses to expand and reach a larger customer base. This process is referred throughout the paper as eTailing. New opportunities are available using this technological method of reaching customers. At the same time, there are some downsides as the face-to-face contact with customers is absent. The logistics, legal issues, and mechanics of using eTailing are discussed throughout the paper.
\end{abstract}

\section{INTRODUCTION}

It is a common misconception that starter businesses (called “startups”) must first have an established brick-and-mortar facility before getting involved in the world of eCommerce or at the very least have a garage full of inventory and shipping supplies on hand.

To date, the most common scenario of entering the world of eCommerce involves the owner of a brick-and-mortar establishment deciding that they need to get their business onto the Internet because they want to tap into the 24/7/365 world-wide audience of growing consumers. It is necessary for the company to build a website so that both the company's brand and its products gain visibility. This might require costly training or the need to hire someone competent enough in web-development and eCommerce to get the company up and running and possibly leave them stranded further down the road. One solution for entrepreneurs is to do the work themselves with the help of online resources or perhaps with the help of a remote support provider or, as Amanda Kooser, author of Support Group, writes:
“Most startups can’t afford to bring a full-time IT person onboard, so entrepreneurs have to get creative and be resourceful. [Asking] other small businesses who they use for IT support [or considering] a remote support provider ... saves you the cost of having an IT person come to your office, and service contracts can help you keep a remote IT technician “on staff””. [7]

Besides, in this day and age, all of the information and resources any one person could need to start an eBiz is available online. Robert Longley's article, Why Small Businesses Fail: SBA, states that "according to the SBA [Small Business Administration], over $50 \%$ of small businesses fail in the first year and 95\% fail within the first five years.” [8] Some of the reasons that Longley mentions in his article as to why startups fail include insufficient capital, poor inventory management, unexpected growth, competition and using business funds for personal use.

\section{Advantages of Starting as an eTail Drop-Shipper}

More advantages than disadvantages can be found for starting out online. For instance, in the world of e-tail dropshipping there are no long lines, no wasted over-head costs because of the slow seasons, and no shop-lifters. Another bonus is that the costs and risks of starting an eBiz are considerably lower than with brick-and-mortar establishments. This kind of business can also be started from home using spare time so that one can grow out of their old job and into their new business.

Another bonus is that so many online venues have become available to the masses to make this eTail drop-shipping dream possible. Ebay has, by far, set the standard and been the most successful online venue for this type of marketing activity. "With $\$ 44.3$ billion in goods sold on eBay in 2005 alone, there is enough room for competition - at least for now - [not to mention], most of the 235 million eBay users are buyers.” [15] 


\section{How Does It All Work?}

Drop-ship eTailing follows the same concept as the Sears \& Roebuck or JC Penney catalogs which are on-line rather than in printed copy. Aside from this article by Small Business Opportunities, a must-read is Chris Malta's eBook, Understanding the Internet for Home Business. Chris Malta is a founding partner and CEO of Worldwide Brands, Inc., co-Host of The Entrepreneur Magazine E-Biz and Product Sourcing Radio Shows, Product Sourcing Editor for The eBay Radio Show, and a best-selling EBiz Author [22].

\section{Getting Started - Business Plan \& Product Sourcing}

The most invaluable resource for any startup is the United States Small Business Administration (sba.gov). From 'Planning Your Business' to 'Local Resources', all of the tools and services necessary to get a solid start can be found here. This site provides a plethora of links to Free Online Courses that teach startups about important topics such as Starting a Business, Writing a Business Plan, Marketing \& Advertising, Bookkeeping and even eCommerce. Also available are convenient links to important tax forms and a plethora of other links to invaluable resources, services and tools for the small business owner.

Every startup should have some kind of business plan to follow - even if it is a simple, one-page outline of what to do and in what order. "A business plan will help keep you on track so you use your limited time wisely, and it also provides a blueprint and onepagebusinessplan.com is a helpful resource to guide you though the process."

Without some form of planning and direction, it is very easy to go off into too many directions and spread valuable resources too thin. This can lead to wasted time and resources and cause unanticipated frustration and delays in the growth of a business. Some helpful tutorials to help determine what steps to take and in what order to take those steps can be found by navigating to smallbusiness.yahoo.com and then clicking the 'Getting Started' link. This page contains links to articles on a variety of startup-related issues. The ' 10 Steps to Open for Business Link' has a number of online tutorials to help get started.

Just because there is a business plan in place does not mean that it has to be followed to the letter. Unless a lending institution is involved where a business plan is expected, then something simple to keep things in perspective is all that is needed. . The business plan should be a general guideline to keep on track and to act as a point of reference. Mark Henricks said it best in his article, On Target: "The business plan is important because it helps you think strategically about your business ... and [it] is a living, organic thing, [as] it continues to change and evolve.” [4] At the very least, putting together a business plan helps the startup owner to answer several key questions, such as what to call the business, what products to sell, and where to sell those products.

The business name usually conveys what it is the business sells or offers so it is a very good idea to know what it is the business will be offering before naming the company. How can a memorable business name be created? "Write down core words - describe what you're offering, then take two of its benefits, two of its functions or two aspects of its appearance, and put them together in a trademarkable term that can become your business name. Keep in mind; it's got to be repeatable.” [14]

Malta writes that, "Product sourcing simply means finding a supplier who sells products at a wholesale price to resell at a retail price. As an eCommerce merchant, the number one thing you have to take care of right away is where you're going to get your product and how much it's going to cost." $[9,10]$ Malta then goes on to give in depth descriptions of the various methods used to locate suppliers for wholesale, light bulk wholesale and drop-ship products. The best method for startups looking for products to sell online is by locating drop-ship wholesale suppliers. He describes this method as follows:

"A drop-shipper is a legitimate wholesale supplier who will deliver a product from the wholesale warehouse directly to your customer. You, as the retailer, never have to touch the product. You use the wholesaler's product literature, including images, description, pricing and warranty info, to make the sale, and then the drop-ship wholesaler delivers the product straight to your customer's door. You don't actually pay for a drop-shipped product until you make the sale to your customer, so you are never spending any money on inventory...[and] Although drop-shipping is an inexpensive product sourcing method in terms of up front costs, it is important to remember that there is a back-end cost 
associated with drop-shipping. Because the wholesale supplier is doing all the work of picking, packing and shipping individual orders for you, they have to charge a little more for the products. It costs the wholesalers more to dropship individual orders for you than it does for them to sell products in bulk, and they have to recoup that cost somehow. Most retailers who use drop-shippers build that drop-ship fee into the handling part of the shipping and handling fees they charge their customers, so they don't have to raise their product prices.” $[9,10]$

Malta emphasizes caution when working with smaller companies because "they have a tendency to run out of stock unexpectedly, especially during the holiday season, and can also go out of business with little or no notice ... As a retailer, you must make sure you're working with genuine, factory-authorized wholesale suppliers ... because the factory-authorized wholesaler is connected directly to the manufacturer, that is also where you will get your best pricing." He also stresses to readers to beware of wholesalers who try to charge an up front fee or companies that do not have their contact information in plain view and to basically run from any wholesaler who makes claims about how much money can be made by signing up with them. Malta concludes his in-depth article about sourcing by mentioning the Better Business Bureau and picking up the telephone and calling potential suppliers as excellent ways of doing your own background check on a company. [9, 10]

\section{Getting Started - Tax \& Legal Formalities}

Now that potential suppliers have been located, it is necessary to apply for various licenses and permits. "With a few clicks of your mouse, you can complete all the legal paperwork required by the government, from the local to the federal level.” [1] These documents are necessary for those who want to deal with legitimate suppliers because a real wholesale supplier will require the retailer to provide their EIN. These documents are also necessary for opening up a business banking account, business eBay account or any other type of account where business information is necessary (i.e. PayPal, BidPay, or Merchant Service companies).

Most eCommerce startups simply start as sole proprietorships and, thus, file for all licenses and permits accordingly. The first formality is to acquire a Business License. This is usually obtained through the County Clerk's office for a small fee and can be applied for online in most cases. The fee depends on factors determined by the county where business will be conducted. It is also a very good idea to check with this office to make sure there are no restrictions for running this type of business from home in the county of residence.

The next formality is to obtain an EIN (Employment Identification Number). This number is also known as a Federal Identification Numbe, and it can be applied for online by visiting the Internal Revenue Service (IRS) at irs.gov online and filling out Federal Form SS-4. [5, 6] The process takes only minutes and the temporary number issued at the end of the process will actually become your permanent EIN. Once this number has been obtained, real relationships with real wholesale suppliers can be formed and all of the necessary forms to open a separate banking and other accounts for business can be completed. Browsing the IRS's Small Business and Self-Employed One-Stop Resource is advised. This is a very informative site for startups and should be bookmarked.

The last formal document needed to conduct business is a State Sales and Use Tax Permit. This has to be obtained from the State Comptroller's office in the state where business is being conducted.

\section{Getting Started - Banking \& Merchant Services}

Now it's time to get everything set up that pertains to dealing with money - namely banking and merchant services. Banking and "Bookkeeping may not be your cup of tea, but it's a necessary part of any business"; and, these bookkeeping [and banking]

basics from Sara Wilson's article, By the Books, will keep your business on track financially:

- $\quad$ Separate Business From Pleasure

- $\quad$ Don’t mix business and personal expenses.

- $\quad$ Open a separate business bank account

- Use a business credit/debit card and keep business receipts separate.

- Don’t Procrastinate - reconcile all accounts regularly.

- $\quad$ Don't Pretend to Know It All - Even if you're handling the daily bookkeeping by yourself, have an accountant on hand to answer the tougher questions regarding deductions, wages and taxes. [20] 
Keeping business and personal finances separate will save both the business owner and the owner's account a lot of grief. Since both accounts payable and accounts receivable will be processed through your bank account -- as well as necessary purchases for the business, such as office supplies and toner refills - it is best to keep a separate banking account that is free of ATM withdrawals, fast-food purchases, and stuff that the kids need for school and extracurricular activities. It is much easier to do bookkeeping and reconcile accounts each month for the business with an account that is free of personal purchases.

Several other money-related accounts that are crucial to conducting business on eBay and online in general and those would be accounts that allow sellers to accept credit card payments from buyers. These types of accounts are known as merchant accounts. The easiest and most accessible merchant account to apply for and use with eBay is eBay's subsidiary, PayPal.com. Another service that is very much like

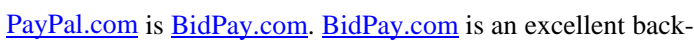
up to have set up in case anything happens at PayPal.com.

Since there have been a number of bad experiences reported regarding PayPal.com locking accounts or freezing funds there are a number of people who will not use this service. This is why it is necessary to have an account with a credit card processor, such as a LinkPoint Central (a Cardservice International subsidiary) or Authorize.net. An account with one of these firms will not only give you a backup methods for accepting payment (i.e. over the phone, via a shopping cart service, in person, etc). It will also give you the versatility to use on additional sites where you sell things including other auction sites or one that you build yourself on your own domain.

\section{Selling on eBay}

Now that all the legal technicalities and banking have been set up and the seller actually has established legitimate accounts with suppliers and merchant services have been acquired so that money can be collected from buyers, it is time to start selling. To get started on eBay, the registration for a free account at eBay.com must be completed.

The next best step for serious selling online is to open an eBay store and subscribe to the Selling Manager and Picture
Manager. The first reason for this is that for a fee of approximately \$15 a month, you will have a wonderful record keeping system to familiarize you with the way listing and selling works as well as access to traffic and selling reports to help you determine which items are drawing the most traffic and revenue. The second reason for doing this is to save a bit of money on eBay's listing fees that pertain to the use of pictures and the listing fees per ad. There is a considerable difference between the cost of placing an ad as an eBay store owner and a non-owner. The savings don't seem like much at first; but, after placing 2000-3000 ads over time it starts to make ' $\phi$ ents'.

If you have experience using HTML, it is also possible to save a little more with free image hosting from sites such as photobucket.com, filmloop.com, slide.com or some other free online image hosting service. In addition to cutting costs, learning to use these sites can help add flair to your ads by allowing you to set up slide shows or film loops to crosspromote items and to add to promotional blogs, email and newsletters. EBay's TurboLister2 supports HTML code from each of the aforementioned sites.

TurboLister2 is a free listing tool that can be downloaded so that ads can be made and saved offline and later uploaded to eBay. "Taking and uploading the photos, posting the item, monitoring the auction ... [can] be time-consuming and downright tedious." [15] Since making and posting ads takes up the majority of time when running an eBay business, it makes sense to use a listing tool that will save you time because as the old cliché goes - 'time is money'. This listing tool saves the seller time because there is little or no lag time between screens like there is with eBay's standard online listing form. Making the first ad and getting all of the particulars ironed out in TurboLister2 can be time consuming; but, once the first ad is done -- complete with all of the pertinent information about shipping, item location, sales tax, payment methods, return policies, etc. - it can be used as a template for future ads. The only changes that need to be made for subsequent ads are the item title, price, picture, description and duration. When the ads are complete then all it takes is a click of the mouse to upload them to eBay. 


\section{Getting the Word Out and Attracting Customers}

Once everything is in place and there are ads in both your Store Inventory and in eBay's online auctions arena, it is time to start selling. The question is - how do you get the word out and get customers interested in your products? In a recent article by Owen Moran, Steve O’Keefe, vice president of the International Association of Online Communicators and author of the Complete Guide to Internet Publicity is quoted as saying, "There's been a dramatic shift to the Internet becoming the dominant form of publicity for most startup businesses, as opposed to a wire service or a printed or faxed news release program with phone call follow-up.” He further stated that "blogs are rocket-fuel publicity [and] mentions on popular blogs can result in an intense amount of activity over a short period of time.” [13]

Building an online presence is the key to success in getting the word out online. Blogs such as Yahoo! 360, MySpace, $\underline{\text { Hi5}}$, are free and take little time to start using and by using certain keywords in the fields for "Favorite Movies" or "Lists" that pertain to your business. You will attract a great deal of traffic to your blog with little effort. By keeping content updated in these venues and by having content that is relevant to what you sell, instead of just using these sites to spam keywords, you will have people become curious enough about you to link to you. Then this will help put you up at the top of some of the leading search engines because --

- "Bloggers often link to sites or other blogs they find interesting, a phenomenon of sharing others' news and information that is virtually nonexistent in mainstream media." [13] .

"Another way to keep a close personal touch is to communicate regularly with clients ... Constancy is important, so consider e-mail, newsletters, e-zines, blogs and teleseminars as ways to keep that connection with clients.” [17, 18, 19] Newsletters by email are by far the least expensive and most effective tool for getting the word out on startup. ConstantContact.com offers a very inexpensive service with tools to help manage bounces and dead email addresses. This "word-of-mouth" method seems like the best and least expensive solution for startups to cultivate and grow their eBiz and gain credibility. You send the newsletter to all of your friends, family and past contacts and ask those people in the mailing to forward it to others who might be interested in your products. McCarthy makes a compelling argument in favor of using the 'word-of-mouth' method to grow in his article, The Power of Suggestion: "In the real world, people make shopping an event; they do it in groups, they browse, share recommendations, and search out reviews by trustworthy experts ... [and], $60 \%$ of U.S. adults who plan to shop on the Web viewed recommendations from friends and family as the top factor when choosing a small online retailer for holiday gift buying, according to a November, 2006 poll from Yahoo! and Harris Interactive.” [11]

Another very good idea is to offer an incentive to get people to buy from you for the first time. Offering a free gift is one great way to reel in customers and "Gifts to clients and customers are also $100 \%$ deductible, subject to tax code limits." [12] Free gifts let a customer know that you've already invested in them in some way - not to mention humans are just naturally curious creatures and they will want to know what that gift is even if they have to buy something to find out. Remember the toy in the cereal box? The free-gift idea is based on the same principle.

Networking is another very effective marketing method of getting the word out. In It's Who You Know, author Eileen F. Sandlin points out that past contacts can be a great source for future business. Sandlin quotes Paul Edwards, co-author of The Best Home Businesses for People 50+, as saying:

"Most self-employed people get new business through wordof-mouth, ... [and], overall, networking is a much more effective way to get business than ... cold-selling.” Sandlin also advocates memberships in professional or trade associations as an effective method to get the word out about your business. [16]

Nicole Torres' article, Get Smart, expands on this idea and relates that "linking yourself with respected members of your target market's community can be an especially effective education tactic ... You can also educate consumers by participating in community activities - [or] donate time or resources to local community services.” $[17,18,19]$

\section{CONCLUSION}

Drop-ship eTailing will change the shopping habits of consumers world-wide and one of the reasons that this venue has gained popularity is the convenience of buying online. 
With so much more to do today and not enough time, more consumers are buying everything from groceries to gifts online and having these items delivered right to their doorstep. This saves the hassle of fighting long lines and traffic, especially during high volume seasons such as Christmas and the mad Back to School rush.

Another reason this venue is gaining such popularity is that there are so many people who would like to work from their own homes to avoid lengthy commutes and to have more time to spend with family and children.

With so many online resources available with a click of a button, starting out online as a drop-ship eTailer on eBay makes perfect sense. The costs are low and so are the risks; however, it will be impossible to succeed without the right attitude. An entrepreneurial spirit is one that not only is bold and innovative, but one that is courageous enough to take responsibility for mistakes. Self-motivation, diligence and persistence are integral to the longevity and success of any business endeavor. Entrepreneurs are motivated by "a love of business and a natural desire to take chances and live outside the comfort zone- to do things that most people wouldn't do themselves. [15]

Romanus Wolter said it best in his article, At Ease, "It's our nature as entrepreneurs to have the personal conviction to overcome most fears; however, we sometimes find ourselves in uncharted waters that cause trepidation...." He says that you can work through these fears if you follow a few simple steps such as being honest about fears, maintaining a positive attitude, declaring a clear outcome before acting, resisting doubt from external sources and by anticipating bumps in the road. [21]

\section{REFERENCES}

1. Cooper, Steve (2007, April 30). For Your Information. Entrepreneur's StartUps, 14.

2. Fitzgerald, Michael (2007, February). The Storage Solution. Inc. Magazine, 50.

3. Gordon, Kim T. (2007, April 30). Sales Shortcuts. Entrepreneur's StartUps, Spring 2007, 56-57.

4. Henricks, Mark (2007, April 30). On Target. Entrepreneur's StartUps, Spring 2007, 18-21.

5. I.R.S., (2007). Small Business and Self-Employed OneStop Resource. Retrieved March 8, 2007, from Internal Revenue Service-United States Department of the
Treasury Web site:

http://www.irs.gov/businesses/small/index.html

6. I.R.S., (2007). Application for Employer Identification Number. Retrieved March 8, 2007, from Internal Revenue Service-United States Department of the Treasury Web site: https://sa2.www4.irs.gov/sa_vign/newFormSS4.doc

7. Kooser, Amanda C. (2007, April 30), Support Group. Entrepreneur's StartUps, 14.

8. Longley, Robert (2007). Why Small Businesses Fail: SBA. Retrieved March 6, 2007, from About: U.S. Gov Info/Resources Web site: http://usgovinfo.about.com/od/smallbusiness/a/whybusf ail.htm

9. Malta, Chris (2007, April 30). Straight to the Source. Entrepreneur's StartUps, Spring 2007, 23-27.

10. Malta, Chris. (2005). Understanding the Internet for Home Business. Worldwide Brands Inc. Retrieved March 3, 2007 from Worldwide Brands Inc. at http://wbi3.worldwidebrands.com/EBook/PDF/Underst andingTheNet.pdf

11. , McCarthy, Ryan (2007, February). The Power of Suggestion. Inc. Magazine, 48-49.

12. . Meyers, Mark (2007, March/April). It. Entrepreneur, March/April 2007, 24.

13. Moran, Gwen (2007, April 30). In the Spotlight. Entrepreneur's StartUps, Spring 2007, 50-55.

14. Park, James (2007, April 30). Total Recall. Entrepreneur's StartUps, 12.

15. Samburg, B. (2007, March/April). Getting Market Value. Success Magazine, 76-81.

16. Sandlin, Eileen F. (2007, April 30). It's Who You Know. Entrepreneur's StartUps, Spring 2007, 70.

17. Torres, Nichole L. (2007, April 30). Get Personal. Entrepreneur's StartUps, 8.

18. Torres, Nichole L. (2007, April 30). Get Smart. Entrepreneur's StartUps, Spring 2007, 15.

19. Torres, Nichole L. (2007, April 30). The Good Life. Entrepreneur's StartUps, 9.

20. Wilson, Sara (2007, April 30). By the Books. Entrepreneur's StartUps, 10.

21. Wolter, Romanus (2007, April 30). At Ease. Entrepreneur's StartUps, Spring 2007, 16.1

22. Worldwide, Brands (2003-2007). Worldwide Brands, Inc.- About Us Page. Retrieved March 7, 2007, from Worldwide Brands, Inc. Web site: http://www.worldwidebrands.com/wwb/about_us.asp\# 